\title{
Development and Evaluation of Solar Battery Charger Coupled with SPV Pumping System
}

\author{
Rajesh M. Dharaskar* , A.G. Mohod, R.T. Thokal and Y.P. Khandetod \\ Dr.B.S.Konkan Krishi.Vidyapeet, Dapoli-415712, Dist. Ratnagiri (MS), India \\ *Corresponding author
}

\section{A B S T R A C T}

\section{Ke ywords \\ Solar Phtovolataic, Water Lifting, Battery charging, Dual application \\ Article Info \\ Accepted: \\ 07 February 2019 Available Online: 10 March 2019}

The solar battery charging station for charging of various farm equipment viz., tractor, power tiller, grass cutter, etc. using $12 \mathrm{~V}$ and $24 \mathrm{~V}$ DC systems was developed and evaluated. The charging station is suitable for coupling with $0.5 \mathrm{hp}$ SPV pumping system suitable for lifting the shallow depth water in remote area. The performance of SPV system for water lifting coupled with charging station was evaluated. The dual application of SPV pumping system and battery charging system facilitates the full utilization of sunshine hours for useful work.

\section{Introduction}

Water is an essential input in any agricultural production system to achieve the desired level of productivity. Majority of the farmers grow their rabi and summer crops by lifting the water from wells, tanks, natural streams, check dams, and canal. In India, lifting water with electric motor does most of the irrigation or diesel engine operated pumps. In most part of country is facing irregular supply of electricity. Similarly the diesel as a natural fuel is becoming more and more scares with the volatility in prices. In the remote areas of the country the availability of either of these two major energy sources is uncertain. Thus, the use of both the energy sources is becoming unreachable for the farmer to irrigate their fields. It emphasizes the use of an alternate energy sources for irrigation and is one of the main infrastructure requirement for the overall development of agriculture has inevitable. Solar photovoltaic (SPV) pumping system may be the best solution to the problem as it is direct utilization of solar energy.

The Konkan region of Maharashtra is a long and narrow strip between $15^{\circ} 3^{\prime} \mathrm{N}$ and $20^{\circ} 20^{\prime}$ $\mathrm{N}$ latitude and $72^{\circ} 7$ ' $\mathrm{E}$ to $74^{0} 30^{\prime} \mathrm{E}$ longitude having latitude up to $500 \mathrm{~m}$ with most of the part is hilly region and adverse topography 
and the region receives rainfall of 2000 to $3500 \mathrm{~mm}$. The adverse topography with dense forest in the region mainly causes the problem of installation of conventional electric grid as well as interrupts the regular electricity supply due to heavy wind and rainfall. In this content the solar photovoltaic pump with low or medium head can be very much suitable for lifting the water from the perennial streams to certain elevation. This system can also be used for lifting the water from shallow ground water. The solar energy in Konkan region is available for 7 to 8 months in a year with an average 6 to 8 bright sunshine hrs/day and intensity of 450 to $600 \mathrm{cal} / \mathrm{cm}^{2}$ day that can be utilized for SPV pumping systems.

Based on the cropping system, type of crop, crop duration and irrigation interval, the solar pumping system cannot operate to its full extend hence reduce the economic benefits. During the ideal condition (no water requirement) of SPV pumping system, the huge converted power from SPV panel was wasted without any useful work. It is necessary to utilize the power available during ideal condition for useful gain. The available power from SPV system can be utilized for battery charging for Inverters, small equipments, lighting, vehicles etc with suitable charging system. The effective utilization of SPV pumping system for battery charging will add the additional benefit to the user.

\section{Materials and Methods}

The study was conducted to evaluate the 0.5 hp capacity SPV pumping system for water lifting at low head and evaluation of coupled battery charging station.

\section{SPV pumping system and experimental layout}

The experimental layout as shown in Figure 1 consists of solar photovoltaic array of 20 panels (100 X $40 \mathrm{~cm}$ size each), with a peak output ranges between 250-300 W capacity, a monoblock centrifugal pump with suction and delivery pipe and water storage and measuring tank. The U-tube manometer was connected to delivery pipe to measure the operating pressure of pump. Centrifugal pump was used to lift the water from a water tank using solar energy. A metallic tank of 50 lit. capacity was used for discharge measurement of the lifted water. The observations of discharge at an interval of one hour from 8.00 am. to $5.00 \mathrm{pm}$. The experimental layout and various components of SPV pumping system is shown in Figure 1.

\section{Determination of efficiencies}

Data collected on incoming solar energy, array output and pump discharge have been used to evaluate the conversion efficiency and pumping efficiency.

\section{Conversion efficiency of SPV array}

The conversion efficiency shows how effectively the solar energy converts the solar radiation in to an electrical energy and it is a function of the purity level of basic material, workmanship in its fabrication and its sensitive to temperature.

Conversion efficiency can be calculated as

Conversion efficiency $(\%)=\frac{\text { Array Output }}{} \times 100$

Total incoming energy

The total incoming energy can be calculated by multiplying the incoming energy (watts/ sq. $\mathrm{m}$ with total panel area in $\mathrm{m}^{2}$.

Incoming energy $\left(\mathrm{W} / \mathrm{m}^{2}\right)=$ Total number of cells $x$ Panel area of each cells $x$ total number of modules

The panel area was found to be $3.26 \mathrm{~m}^{2}$. 


\section{Pumping efficiency of SPV array}

The pumping efficiency can be determined as

$$
\text { Pumping Efficiency }=\frac{\text { Water Horse Power }(W)}{\text { Array out put }(W)} X 1
$$

The Water power can be calculated as

Water horse power $(W)=$

$$
\frac{\text { Total head (m) X Pump discharge (lit/sec) }}{75} \text { X746 }
$$

\section{Solar PV operated battery charger}

The solar PV operated charging station coupled with water pumping was developed. The SPV based charging station consist of various components as

\section{SVP pumping system}

It is used to convert solar energy into electrical energy. The SPV pump having solar panel $(72 \mathrm{~V}, 5$ A current with max. output$375 \mathrm{wp}$ ) will act as a main source of energy for battery charging during ideal condition.

\section{Main charger}

It consists of electronic circuit which is used to regulate the power supply at fixed voltage. It will charge the main battery bank $(48 \mathrm{~V}$, $3 \mathrm{~A}$ ) and prevent the reverse flow from the battery to the panel during night time.

\section{Battery bank}

A battery bank which is charged by the main charger will act as a charge reservoir for uninterrupted power supply at fixed voltage.

\section{Terminal charging units}

It consist of an electronic circuit which provide the constant supply of $12 \mathrm{~V}, 5 \mathrm{~A}$ and
$24 \mathrm{~V}, 4$ A simultaneously for charging the two different batteries of $12 \mathrm{~V}$ and $24 \mathrm{~V}$ using the two way switch. The layout of SPV pumping system and coupled solar battery charger is shown in Figure 2.

The electronic circuit is developed by using the component as shown in table 1 and 2 for DC to DC converter from $48 \mathrm{~V} / 3 \mathrm{~A}$ to $12 \mathrm{~V} / 5 \mathrm{~A}$ and $48 \mathrm{~V} / 3 \mathrm{~A}$ to $24 \mathrm{~V} / 4 \mathrm{~A}$ along with charging and discharging controller and protection for battery bank and end use appliances.

The solar battery charger was tested for charging the $12 \mathrm{~V}$ battery and $24 \mathrm{~V}$ batteries which are commonly used for various applications. The solar charger was also tested for time required for charging the battery bank of 4 nos. $12 \mathrm{~V}$ connected in series.

\section{Results and Discussion}

The conservation efficiency of SPV unit is the ability of solar photovoltaic cells to convert the light part of solar insolation into electricity. The conversion efficiency of solar panel gives an input to the solar photovoltaic pumping system thus it was evaluated for the daytime operation during Rabi season. Solar radiation and other climatic parameters, being the main source of input to solar photovoltaic, the combined effect of all these parameters on conversion efficiency of solar panel was evaluated by multiple regression analysis and is illustrated in Figure 3.

Conversion efficiency found to be varying from $5.67 \%$ to $17.61 \%$. Initially the conversion efficiency was higher and it declines as the elapsed time progressed and again it was seen steadily increasing up to 4.00 p.m.

It was highest at the evening (5.00 p.m.). The most influencing parameter in isolation among considered was found to be solar insolation. 
Evaluation of solar photovoltaic pump characters

The solar photovoltaic pump was evaluated for the discharge at lower and higher heads and the pump characteristics viz. pump discharge, pump efficiency and operation time were determined and are discussed in the following sections.

Table.1 Electrical circuit components used for battery charging

\begin{tabular}{|ll|ll|}
\hline 1-SL100 & R1-4.7k & D1-BYV79 & C1-680p \\
T2-BC148 & R2-200 ohm & R1-1K & C2-470u/35v \\
VR1-4.7K & R3-47 ohm & R2-1ohm/4w & C3-470u/35v \\
C2-100 uf/25v & R4-10k & R3-1ohm/4w & C4-1000uf/16v \\
C1-470uf/25v & R5-10k & R4-18k & T1-BUZ10 \\
Z1-1w zener reqd voltage & R5-1.2k & IC 1- \\
& & TLO82/TL497A & \\
& & P1-10k & L1-30uH \\
& & & \\
\hline
\end{tabular}

Table.2 Battery charger circuit

\begin{tabular}{|l|l|}
\hline R1-1.8k & L1-LED overcharge \\
R2-1.8k & L2- LED cut off \\
R3-1.8k & S1-SCRTY1016 \\
R4-3.3k & D1-1N4001 \\
R5-330 ohm & Z1-8.2 V \\
R6-3.3k & C1-100 uf/50v \\
P1-4.7k & CB-Ckt.braker \\
& R-Relay coil \\
\hline
\end{tabular}

Table.3 Charging of battery bank (4Nos, $12 \mathrm{~V}$ each connected in series)

\begin{tabular}{|l|c|c|}
\hline Time & Sun intensity, luxx100 & Voltage level \\
\hline $09.00 \mathrm{am}$ & 695 & $10 \mathrm{~V}$ \\
\hline $10.00 \mathrm{am}$ & 870 & $17 \mathrm{~V}$ \\
\hline $11.00 \mathrm{am}$ & 1084 & $24 \mathrm{~V}$ \\
\hline $12.00 \mathrm{pm}$ & 1135 & $35 \mathrm{~V}$ \\
\hline $01.00 \mathrm{pm}$ & 1270 & $40 \mathrm{~V}$ \\
\hline $02.00 \mathrm{pm}$ & 1190 & $45 \mathrm{~V}$ \\
\hline $03.00 \mathrm{pm}$ & 908 & $48 \mathrm{~V}$ \\
\hline $04.00 \mathrm{pm}$ & 665 & $51 \mathrm{~V}$ \\
\hline $05.00 \mathrm{pm}$ & 335 & $51.5 \mathrm{~V}$ \\
\hline
\end{tabular}


Table.4 Charging of 12 Volt, 17 AH sealed lead acid battery

\begin{tabular}{|l|c|c|}
\hline Time & Sun intensity, lux x100 & Voltage level \\
\hline $09.00 \mathrm{am}$ & 324 & $05.60 \mathrm{~V}$ \\
\hline $10.00 \mathrm{am}$ & 745 & $07.50 \mathrm{~V}$ \\
\hline $11.00 \mathrm{am}$ & 965 & $10.45 \mathrm{~V}$ \\
\hline $12.00 \mathrm{pm}$ & 1114 & $11.98 \mathrm{~V}$ \\
\hline $01.00 \mathrm{pm}$ & 1172 & $12.00 \mathrm{~V}$ \\
\hline $02.00 \mathrm{pm}$ & 1060 & $12.05 \mathrm{~V}$ \\
\hline $04.00 \mathrm{pm}$ & 570 & $12.06 \mathrm{~V}$ \\
\hline
\end{tabular}

Table.5 Charging of 24 Volt (12V, 17 AH 2 Nos. connected in series) Battery

\begin{tabular}{|l|c|c|}
\hline Time & Sun intensity, lux x100 & Voltage level \\
\hline 12.00 & 1075 & $17.00 \mathrm{~V}$ \\
\hline $01.00 \mathrm{pm}$ & 1175 & $21.60 \mathrm{~V}$ \\
\hline $02.00 \mathrm{pm}$ & 1062 & $23.50 \mathrm{~V}$ \\
\hline $03.00 \mathrm{pm}$ & 835 & $23.7 \mathrm{~V}$ \\
\hline $04.00 \mathrm{pm}$ & 540 & $23.80 \mathrm{~V}$ \\
\hline $05.00 \mathrm{pm}$ & 435 & $23.90 \mathrm{~V}$ \\
\hline
\end{tabular}

Fig.1 Experimental layout of SPV pumping system

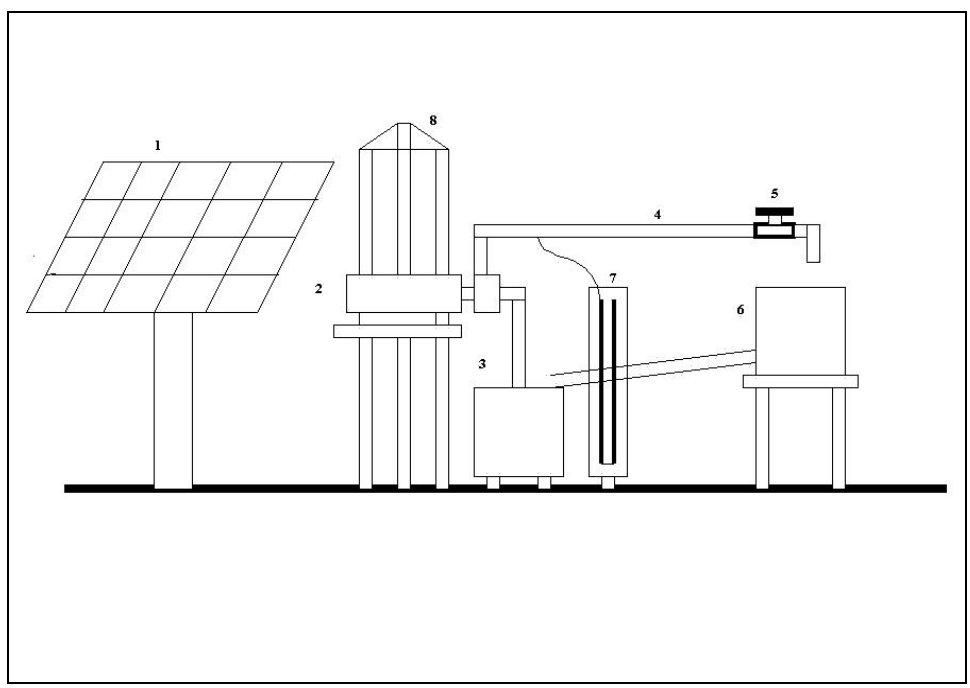

1. Solar Panel

2. SPV Operated Pump

3. Water Storage Tank

4. Delivery Pipe

5. Valve

6. Measuring Tank

7. Manometer

8. Stand 
Fig.2 SPV pumping system coupled with battery charger

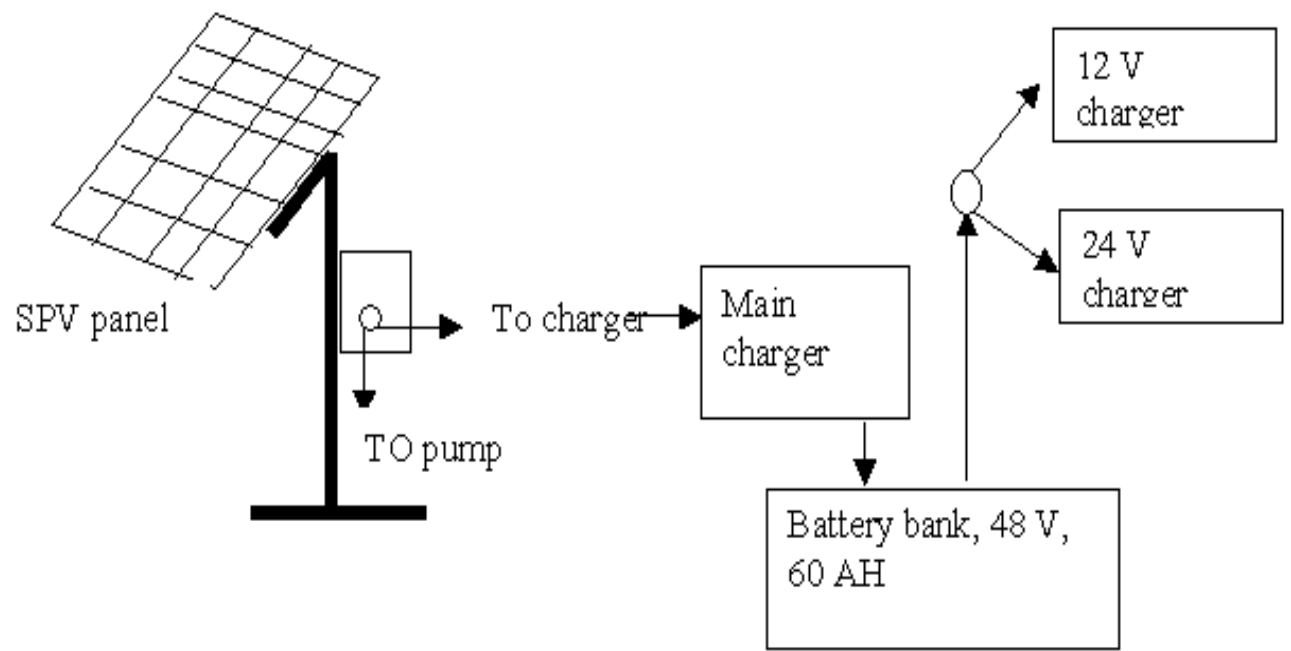

Fig.3 Combined effects of radiation, temperature, relative humidity, wind velocity and elapsed time on conversion efficiency

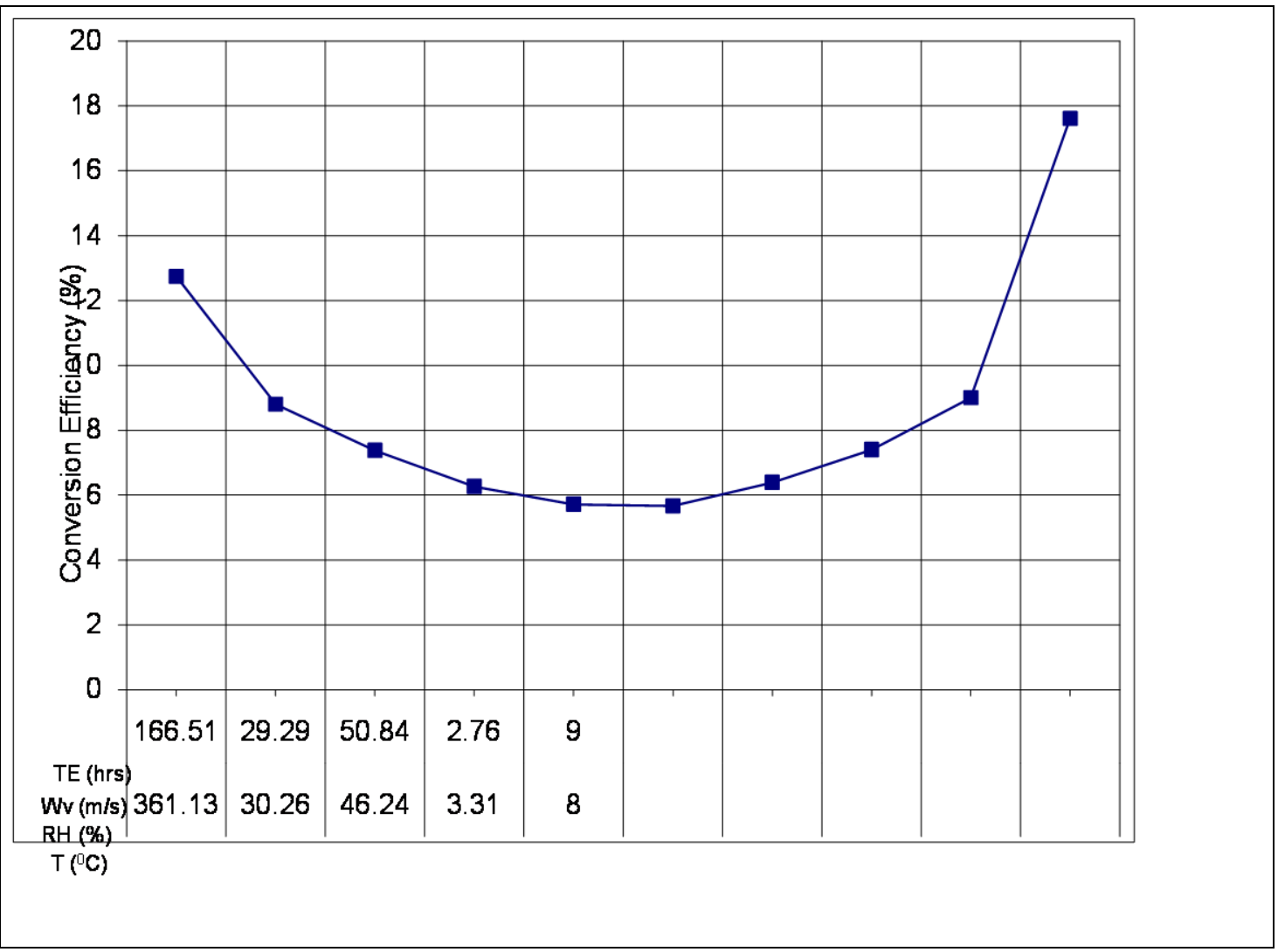

Note: Elapsed time as '0' indicates '8.00 a.m.' and '9' indicates '5.00 p.m.' 
Fig.4 Pump characteristics against time for lower head operation

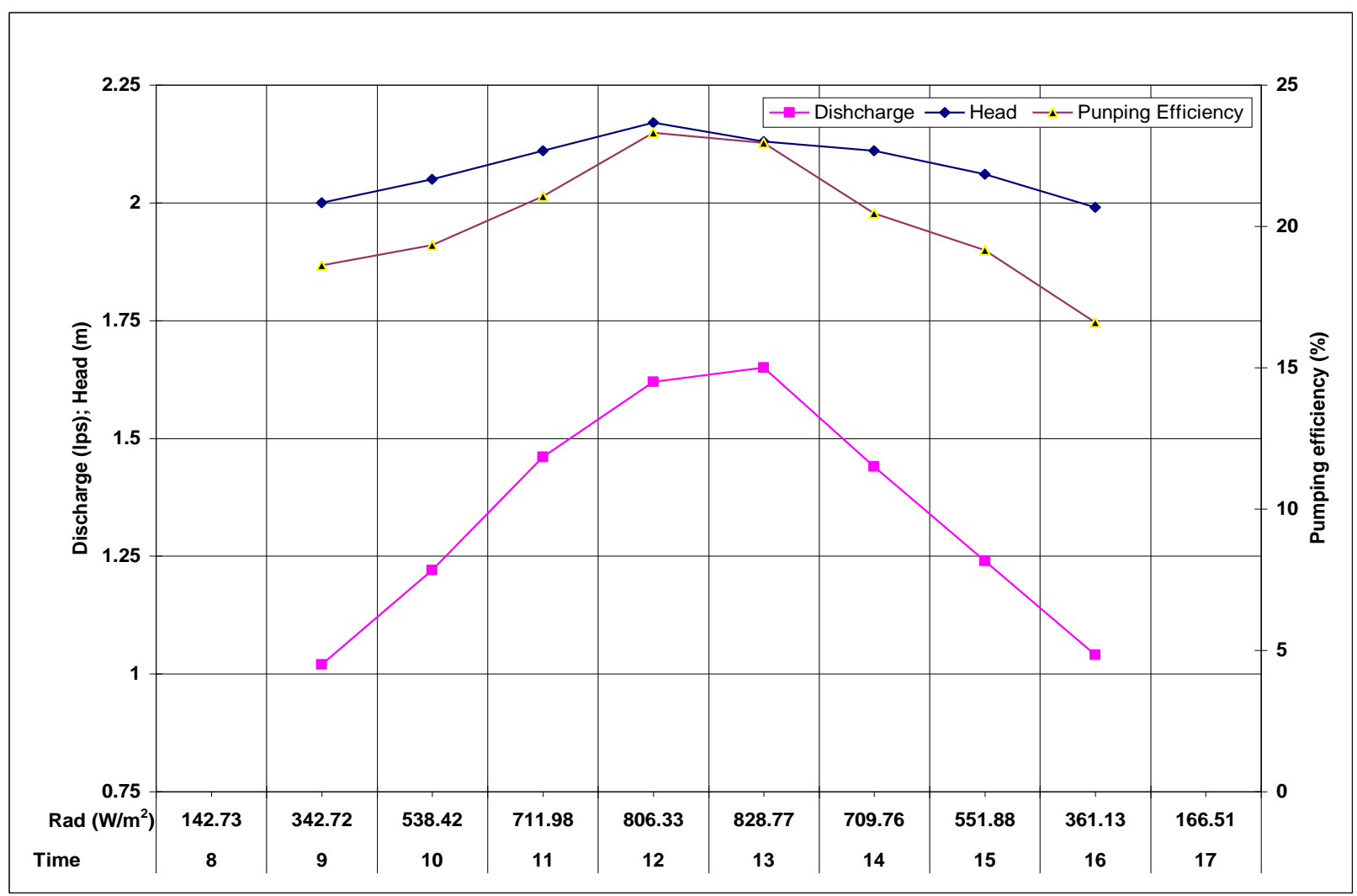

\section{Pump operated at lower head}

During the morning (8.00 to 9.00 a.m.) and evening (4.00 to 5.00 p.m.) hours of operation the discharge was very low, however the conversion efficiency during these hours was higher so it was omitted. During the operation period from 9.00 a.m. to 4.00 p.m., it is seen that from Figure 4 at lower head operation, the total head lifted by pump was approximately constant with an average of $2.07 \mathrm{~m}$ and while the discharge was found to be varying from 1.02 to $1.65 \mathrm{lit} / \mathrm{sec}$ with an average value of $1.394 \mathrm{lit} / \mathrm{sec}$.

Pumping efficiency for lower head remained almost constant with slight increasing trend from 11.00 a.m. to 12.00 noon and decreasing thereafter. Increasing trend may be due to increased radiation and temperature during that period. Pumping efficiency was seen to be ranging from $19.15 \%$ to $23.3 \%$ with an average of $20.03 \%$.

\section{Testing of solar battery charger}

The result obtained from testing of the battery charger is depicted in the tables 3,4 , and 5 .

It is observed that the average time required for charging the battery bank $10 \mathrm{~V}$ discharge level to $51 \mathrm{~V}$ full charged level is about 08 hours during the bright sunshine hours. The average time required for charging the $12 \mathrm{~V}$, $17 \mathrm{AH}$ sealed lead acid battery from $5.6 \mathrm{~V}$ discharge level to $12.06 \mathrm{~V}$ full charge level is about 06 hours. The average time required for charging the $24 \mathrm{~V} 17 \mathrm{Ah} \times 2$ nos connected in series from $17 \mathrm{~V}$ to $23.9 \mathrm{~V}$ is about 05 hours. The overall cost of charger is found to be Rs. 9000/- without battery bank. 
In conclusion, the solar battery charger works satisfactorily. The avg. time required to charge the $12 \mathrm{~V}, 17 \mathrm{AH}$ battery and $24 \mathrm{~V}$ $(12 \mathrm{~V}, 2 \mathrm{Nos}$ in series) is about 06 hours and 05 hours respectively. The total cost of the charger is about Rs 9000/- without battery bank.

\section{References}

Chau, K. V., (1982). Optimum tilt angles for solar collectors in clear sky conditions. Journal of Agril. Engg. Research, 274(4): 321-328.

Fitzgerald, A. E., Charles Kingsley, and Alexander Kisko (1971). Electric Machinery $3^{\text {rd }}$ edition McGraw Hill International Book Company.

Green, M. A. (1982). Solar Cells. Operating Principles, Technology, and System Applications, Pretence Hall, Inc.

Kharche, S. D. (1997). Design and fabrication of low cost sun tracking system for solar photovoltaic module, unpublishepd B.Tech. project thesis submitted to the College of Agricultural Engineering and Technology, Dr. Panjabrao Deshmukh Krishi Vidyapeeth, Akola.

Mosher, D. M. R., R. E. Boese, R. J. Soukup (1977). The advantages of sun tracking for planar silicon solar cells, Solar Energy, Great Britain, 19: 9197.

Narendra Haridas Tayade and Regi Kuttappan (1999). Design and fabrication of solar photoboltaic tracking system using stepper motor, unpublished B.Tech. project thesis submitted to the College of Agricultural Engineering and Technology, Dr. Panjabrao Deshmukh Krishi Vidyapeeth, Akola.

Tsalides, P. and A. Thanailakis (1955). Direct computation of the array optimum tilt angle in constant tilt photovoltaic systems, Solar cells, 14: 83-84.

\section{How to cite this article:}

Rajesh M.Dharaskar, A.G. Mohod, R.T. Thokal and Khandetod, Y.P. 2019. Development and Evaluation of Solar Battery Charger Coupled with SPV Pumping System. Int.J.Curr.Microbiol.App.Sci. 8(03): 445-452. doi: https://doi.org/10.20546/ijcmas.2019.803.056 